\title{
Performance Evaluation of the Products of Different Drip and Sprinkler Irrigation Companies
}

\author{
V.L. Pawar, V.D. Paradkar* and Pradip Dalavi \\ College of Technology and Engineering, MaharanaPratap University of Agriculture and \\ Technology, Udaipur, Rajasthan, India \\ *Corresponding author
}

\section{A B S T R A C T}

The research was carried out to evaluate the performance of drip and sprinkler irrigation products manufactured by different companies viz. Company A, Company B and Company C. Two NPC emitters of $4 \mathrm{lph}$ and $8 \mathrm{lph}$ were tested at operating pressure ranging from 0.5

Keywords

Drip, Sprinkler,

Products,

Companies,

Performance

Evaluation etc.

Article Info

Accepted:

17 October 2017

Available Online:

10 December 2017 to $1.25 \mathrm{~kg} / \mathrm{cm}^{2}$ and one PC emitter of 4 lph discharge was tested at same operating pressure range. Also, sprinkler of $120 \mathrm{lph}$ discharge was tested at operating pressure ranging from 0.75 to $1.5 \mathrm{~kg} / \mathrm{cm}^{2}$. The Emission Uniformity (EU) and Coefficient of Uniformity (CU) of system were worked out. In $4 \mathrm{lph}$ and $8 \mathrm{lph}$ NPC drippers manufactured by Company A, discharge variation with respect to pressure was less as compare to standard discharge values of Company B and Company C. In 4 lph PC drippers manufactured by Company B, discharge variation with respect to pressure was very less as compared to standard discharge values of Company A and Company C. It was observed that with increase in pressure from $0.75 \mathrm{~kg} / \mathrm{cm}^{2}$ to $1.50 \mathrm{~kg} / \mathrm{cm}^{2}$, discharge increased from $57.93 \mathrm{lph}$ to $118 \mathrm{lph}$ for sprinkler manufactured by Company A and from $44.2 \mathrm{lph}$ to $113 \mathrm{lph}$ for sprinkler manufactured by Company B. The highest UC of $90.13 \%$ was found at $1.5 \mathrm{~kg} / \mathrm{cm}^{2}$ for sprinkler manufactured by Company A and $88.80 \%$ for sprinkler manufactured by Company B at same pressure. Sprinkler of 120 lph manufactured by Company A given excellent performance with minimum variation in discharge as compared to that of Company B.

\section{Introduction}

The field application efficiency in most traditional irrigation methods is still very low, typically less than $50 \%$ (sprinkler irrigation) and often as low as $30 \%$ (surface irrigation) (Molden et al., 2010). The excessive application of water generally entails losses because of surface run-off from the field and deep percolation below the root zone within the field. An alternative water application method like drip and sprinkler irrigation allow for much more uniform distribution as well as more precise control of the amount of water applied and also decreases nutrient leaching (Mistry et al., 2014).Thesesystems are water saving, energy saving, and weeds and disease control methods. Also land levelling is not required for irrigating crops using sprinkler irrigation. Light textured soils can be irrigated properly. Accurate and precise depth of water can be applied using sprinkler irrigation. In future there is a need of giving knowledge about micro irrigation; its importance and maintenance to the farmer in easy way (Deshmukh et al., 2014). 
For achieving high efficiency of water, use of drip and sprinkler irrigation are the most appropriate technologies in modern irrigated agriculture with the great potential (Abdurazzaq and Aziz, 2013). It also leads itself to easy adoption for chemigation and automation (Sharma, 2013). These systems permit controlling of discharge and flexibility in time of water application. Drip irrigation saves water to the extent of 30 to $70 \%$ without significantly affecting the crop yield (Mohammed et al., 2013). Sprinkler system also saves water to the extent of $35 \%$ over furrow irrigation without significantly affecting the crop yield. Today, there are number of drip and sprinkler manufacturing companies available in the market. But these companies provide variety of products to the farmers of various qualities at different rates. The farmers are unaware of performance of product and they select the product having lower cost. Therefore the present investigation was undertaken to enable the farmers to select most appropriate products of specific company.

\section{Materials and Methods}

The research was carried out at Puriya Park Farm, K. K. Wagh College of Agricultural Engineering and Technology, Nashik, Maharashtra, India. The performance of drip and sprinkler products of different companies was evaluated with various performance parameters.

The selection of lateral for testing was done on the basis of commonly used diameter of lateral i.e. $16 \mathrm{~mm}$ size. The emitters selected were 4 lph and 8 lph Non Pressure Compensating (NPC) and 4 lph Pressure Compensating (PC), manufactured by Company A, Company Band Company C. These emitters were tested at different pressures ranging from 0.50 to $1.25 \mathrm{~kg} / \mathrm{cm}^{2}$ with an increment of $0.25 \mathrm{~kg} / \mathrm{cm}^{2}$.
Components of drip and sprinkler irrigation testing system

Water conveying system

Laterals

Emitters

Sprinkler heads with riser pipe

Catch cans

Fitting accessories

Pressure gauge

\section{Set-up for drip and sprinkler testing unit}

The testing unit was used to test the drippers and sprinklers of different companies. The emitters were spaced at $30 \mathrm{~cm}$ on the $4 \mathrm{~m}$ lateral having $16 \mathrm{~mm}$ diameter. The emitters were tested at different pressure ranging from 0.5 to $1.25 \mathrm{~kg} / \mathrm{cm}^{2}$ with an increment of 0.25 $\mathrm{kg} / \mathrm{cm}^{2}$. Similarly, the sprinklers were tested at different pressure ranging from 0.75 to 1.5 $\mathrm{kg} / \mathrm{cm}^{2}$ with an increment of $0.25 \mathrm{~kg} / \mathrm{cm}^{2}$.

\section{Evaluation parameters for drip and} sprinkler system

Pressure discharge relationship, emission uniformity and coefficient of uniformity were used to evaluate the performance of products from different drip companies viz. Company A, Company B and Company C. Similar parameters were used for evaluating performance of sprinklers of Company A and Company B.

\section{Pressure discharge relationship}

The lateral was joined with the emitters of 4 lph to the inlet pipe. Then the pressure of 0.5 $\mathrm{kg} / \mathrm{cm}^{2}$ was adjusted with the help of control valve. The catch cans were kept below each of the emitter for collecting the discharge through emitters. Similarly for sprinkler system the pressure of $0.75 \mathrm{~kg} / \mathrm{cm}^{2}$ was adjusted with the help of control valve. The catch cans were placed at grid points of 0.75 
$\mathrm{X} 0.75 \mathrm{~m}$ to collect the precipitation. Then both systems were operated for $5 \mathrm{~min}$. The depth of water collected in each cylinder or catch can was measured. The pressure discharge relationship was determined using the formula given by Keller and Karmelli (Mane and Ayare, 2007).

$\mathrm{q}=\mathrm{K}_{\mathrm{e}} \mathrm{H}^{\mathrm{X}}$

Where,

$\mathrm{q}=$ Discharge rate of dripper (lph)

$\mathrm{K}_{\mathrm{e}}=$ Discharge coefficient

$\mathrm{H}=$ Pressure head $(\mathrm{m})$

$\mathrm{X}=$ Dripper flow exponent

The same procedure was repeated for various companies emitters.

\section{Emission uniformity (EU)}

Both drip and sprinkler systems were operated for $5 \mathrm{~min}$ and the volume of water collected in each catch can was measured. The emission uniformity was determined using the following formula given by Keller and Karmelli (Mane and Ayare, 2007).

$\mathrm{EU}=\left(\mathrm{q}_{\min } / \mathrm{q}_{a v g}\right) \times 100$

Where,

$\mathrm{EU}=$ Emission Uniformity (\%)

$\mathrm{q}_{\text {min }}=$ Minimum emitter discharge (lph)

$\mathrm{q}_{\text {avg }}=$ Average emitter discharge (lph)

\section{Uniformity coefficient (UC)}

UC was determined by Christiansen's formula (Mane et al., 2006) as under,

$\mathrm{UC}=\left[1-\left(\frac{\Sigma \mathrm{X}}{\mathrm{Mn}}\right)\right] \mathrm{X} 100$

Where,
$\mathrm{UC}=$ Coefficient of uniformity $(\%)$

$\mathrm{M}=$ Average value of all observations

$\mathrm{n}=$ Total number of observation points

$\mathrm{X}=$ Numerical deviation of all observation

To determine the UC of sprinkler system, a grid of spacing $0.75 \mathrm{X} 0.75 \mathrm{~m}$ was made in representative area. The catch cans were placed at grid points to collect the precipitation. The duration of test run was 15 minutes. The volume collected in each catch can was measured. The rate of precipitation in each catch can was computed by knowing volume of water collected in each catch can and then dividing it by surface area of catch can.

The mean of precipitation rate of all catch cans was calculated to know average rate of precipitation. The UC was determined for operating pressure of $0.75,1.0,1.25$ and 1.50 $\mathrm{kg} / \mathrm{cm}^{2}$ for micro-sprinkler. Initially system was operated for pressure of $0.75 \mathrm{~kg} / \mathrm{cm}^{2}$ and the observations were recorded. The same procedure was repeated for other operating pressures and micro-sprinkler spacing combinations.

\section{Results and Discussion}

Pressure discharge relationship for emitters

The observations of operating pressure and corresponding discharges were recorded.

\section{NPC Emitters (4 lph)}

With increase in pressure discharge increased, for 4 lph NPC drippers manufactured by Company A (Table 1).

With increase in pressure from $0.5 \mathrm{~kg} / \mathrm{cm}^{2}$ to $1.25 \mathrm{~kg} / \mathrm{cm}^{2}$, discharge increased from 1.44 lph to $4.06 \mathrm{lph}$, for $4 \mathrm{lph}$ NPC emitters manufactured by Company B (Table 2). 
With increase in pressure from $0.5 \mathrm{~kg} / \mathrm{cm}^{2}$ to $1.25 \mathrm{~kg} / \mathrm{cm}^{2}$, discharge increased from 1.50 lph to $4.1 \mathrm{lph}$, for $4 \mathrm{lph}$ NPC emitters manufactured by Company $\mathrm{C}$ which means that discharge increased with increase in operating pressure (Table 3). Similar results were reported by Chavan et al., 2009.

\section{NPC Emitters (8 lph)}

With increase in pressure, discharge increased for 8 lph NPC dripper, manufactured by Company A (Table 4).

It was observed that, as the operating pressure increased from 0.5 to $1.25 \mathrm{~kg} / \mathrm{cm}^{2}$, discharge increased from $4.20 \mathrm{lph}$ to $7.91 \mathrm{lph}$, for $8 \mathrm{lph}$ NPC emitters manufactured by Company B. (Table 5).

It was observed that with increase in pressure, the discharge also increased but there was variation in the calculated discharge as compared to the standard discharge given by Company Cfor 8 lph NPC emitters (Table 6).

\section{PC emitters (4 lph)}

It was observed that with increase in pressure, there was variation in the discharge to small extent as per manufacturer's standard for 4 lph PC drippers manufactured by Company A (Fig. 1).
It was observed that with increase in pressure, there was change in discharge. There was less variation in calculated and standard discharge. 4 lph PC drippers manufactured by Company $B$ gave uniform discharge than drippers manufactured by Company B (Fig. 2).

With increase in operating pressure, the average discharge remained nearly same. There were minor variations in the discharge for the emitter manufactured by Company $\mathrm{C}$ (Fig. 3). Similar results were reported by Kyada and Munjapara (2013).

Pressure discharge relationship for sprinkler

It was observed that with increase in pressure from $0.75 \mathrm{~kg} / \mathrm{cm}^{2}$ to $1.50 \mathrm{~kg} / \mathrm{cm}^{2}$, discharge increased from $57.93 \mathrm{lph}$ to $118 \mathrm{lph}$, which means that discharge increased with increase in operating pressure for mini sprinkler manufactured by Company A (Table 7).

It was observed that with increase in pressure from $0.75 \mathrm{~kg} / \mathrm{cm}^{2}$ to $1.50 \mathrm{~kg} / \mathrm{cm}^{2}$, discharge increased from $44.2 \mathrm{lph}$ to $113 \mathrm{lph}$.

The optimum discharge can be obtained at 1.5 $\mathrm{kg} / \mathrm{cm}^{2}$ pressure but discharge obtained was 113 lph which may due to manufacturing defect or human error in noting the readings (Table 8).

Table.1 Average discharge of 4 lph NPC emitter (Company A) at different operating pressures

\begin{tabular}{|c|c|c|c|}
\hline Sr. No. & $\begin{array}{c}\text { Operating pressure } \\
\left(\mathbf{k g} / \mathbf{c m}^{\mathbf{2}}\right)\end{array}$ & $\begin{array}{c}\text { Calculated Discharge } \\
(\mathbf{l p h})\end{array}$ & $\begin{array}{c}\text { Standard Discharge } \\
(\mathbf{l p h})\end{array}$ \\
\hline 1. & 0.50 & 1.55 & 2.90 \\
\hline 2. & 0.75 & 2.90 & 3.30 \\
\hline 3. & 1.00 & 3.85 & 4.0 \\
\hline 4. & 1.25 & 4.10 & 4.20 \\
\hline
\end{tabular}


Table.2 Average discharge of 4 lph NPC emitter (Company B) at different operating pressures

\begin{tabular}{|c|c|c|c|}
\hline Sr. No. & $\begin{array}{c}\text { Operating pressure } \\
\left(\mathbf{k g} / \mathbf{c m}^{\mathbf{2}}\right)\end{array}$ & $\begin{array}{c}\text { Calculated Discharge } \\
(\mathbf{l p h})\end{array}$ & $\begin{array}{c}\text { Standard } \\
\text { Discharge(lph) }\end{array}$ \\
\hline 1. & 0.50 & 1.44 & 2.90 \\
\hline 2. & 0.75 & 2.80 & 3.40 \\
\hline 3. & 1.00 & 3.80 & 4.00 \\
\hline 4. & 1.25 & 4.06 & 4.40 \\
\hline
\end{tabular}

Table.3 Average discharge of 4 lph NPC emitter (Company C) at different operating pressures

\begin{tabular}{|c|c|c|c|}
\hline Sr. No. & $\begin{array}{c}\text { Operating pressure } \\
\left(\mathbf{k g} / \mathbf{c m}^{\mathbf{2}}\right)\end{array}$ & $\begin{array}{c}\text { Calculated Discharge } \\
(\mathbf{l p h})\end{array}$ & $\begin{array}{c}\text { Standard Discharge } \\
(\mathbf{l p h})\end{array}$ \\
\hline 1. & 0.50 & 1.50 & 2.80 \\
\hline 2. & 0.75 & 2.90 & 3.40 \\
\hline 3. & 1.00 & 3.80 & 4.01 \\
\hline 4. & 1.25 & 4.10 & 4.45 \\
\hline
\end{tabular}

Table.4 Average discharge of 8 lph NPC emitter (Company A) at different operating pressures

\begin{tabular}{|c|c|c|c|}
\hline Sr. No. & $\begin{array}{c}\text { Operating pressure } \\
\left(\mathbf{k g} / \mathbf{c m}^{\mathbf{2}}\right)\end{array}$ & $\begin{array}{c}\text { Calculated Discharge } \\
(\mathbf{l p h})\end{array}$ & $\begin{array}{c}\text { Standard Discharge } \\
(\mathbf{l p h})\end{array}$ \\
\hline 1. & 0.50 & 4.42 & 6.00 \\
\hline 2. & 0.75 & 5.70 & 6.95 \\
\hline 3. & 1.00 & 7.10 & 8.00 \\
\hline 4. & 1.25 & 7.83 & 8.50 \\
\hline
\end{tabular}

Table.5 Average discharge of 8 lph NPC emitter (Company B) at different operating pressures

\begin{tabular}{|c|c|c|c|}
\hline Sr. No. & $\begin{array}{c}\text { Operating pressure } \\
\left(\mathbf{k g} / \mathbf{c m}^{\mathbf{2}}\right)\end{array}$ & $\begin{array}{c}\text { Calculated Discharge } \\
(\mathbf{l p h})\end{array}$ & $\begin{array}{c}\text { Standard Discharge } \\
(\mathbf{l p h})\end{array}$ \\
\hline 1. & 0.50 & 4.20 & 6.07 \\
\hline 2. & 0.75 & 4.52 & 7.06 \\
\hline 3. & 1.00 & 6.56 & 8.00 \\
\hline 4. & 1.25 & 7.91 & 8.75 \\
\hline
\end{tabular}

Table.6 Average discharge of 8 lph NPC emitter Company C at different operating pressures

\begin{tabular}{|c|c|c|c|}
\hline Sr. No. & $\begin{array}{c}\text { Operating pressure } \\
\left(\mathbf{k g} / \mathbf{c m}^{\mathbf{2}}\right)\end{array}$ & $\begin{array}{c}\text { Calculated Discharge } \\
(\mathbf{l p h})\end{array}$ & $\begin{array}{c}\text { Standard Discharge } \\
(\mathbf{l p h})\end{array}$ \\
\hline 1. & 0.50 & 4.10 & 6.0 \\
\hline 2. & 0.75 & 5.40 & 6.9 \\
\hline 3. & 1.00 & 6.50 & 7.02 \\
\hline 4. & 1.25 & 7.70 & 8.65 \\
\hline
\end{tabular}


Table.7 Average discharge at different operating pressure for 120 lph sprinkler head (Company A)

\begin{tabular}{|c|c|c|}
\hline Sr. No. & Operating pressure $\mathbf{( k g / \mathbf { c m } ^ { 2 } )}$ & Discharge (lph) \\
\hline 1. & 0.75 & 57.93 \\
\hline 2. & 1.00 & 70.50 \\
\hline 3. & 1.25 & 97.53 \\
\hline 4. & 1.50 & 118 \\
\hline
\end{tabular}

Table.8 Average discharge at different operating pressure for 120 lph sprinkler head (Company B)

\begin{tabular}{|c|c|c|}
\hline Sr. No. & Operating pressure $\mathbf{( k g / \mathbf { c m } ^ { 2 } )}$ & Discharge (lph) \\
\hline 1. & 0.75 & 44.2 \\
\hline 2. & 1.00 & 64.50 \\
\hline 3. & 1.25 & 72.11 \\
\hline 4. & 1.50 & 113 \\
\hline
\end{tabular}

Table.9 Variation in EU for different operating pressure for 4 lph NPC emitter (Company A)

\begin{tabular}{|c|c|c|}
\hline Sr. No. & Operating pressure $\mathbf{( k g / \mathbf { c m } ^ { 2 } )}$ & Emission Uniformity (\%) \\
\hline 1. & 0.50 & 96.77 \\
\hline 2. & 0.75 & 96.55 \\
\hline 3. & 1.00 & 98.70 \\
\hline 4. & 1.25 & 97.68 \\
\hline
\end{tabular}

Table.10 Variation in EU for different operating pressure for 4 lph NPC emitter (Company B)

\begin{tabular}{|c|c|c|}
\hline Sr. No. & Operating pressure $\mathbf{( k g / \mathbf { c m } ^ { 2 } )}$ & Emission Uniformity (\%) \\
\hline 1. & 0.50 & 97.22 \\
\hline 2. & 0.75 & 98.21 \\
\hline 3. & 1.00 & 99.93 \\
\hline 4. & 1.25 & 99.01 \\
\hline
\end{tabular}

Table.11 Variation in EU for different operating pressure for 4 lph NPC emitter (Company C)

\begin{tabular}{|c|c|c|}
\hline Sr. No. & Operating pressure $\mathbf{( k g / \mathbf { c m } ^ { 2 } )}$ & Emission Uniformity (\%) \\
\hline 1. & 0.50 & 96.66 \\
\hline 2. & 0.75 & 98.96 \\
\hline 3. & 1.00 & 98.40 \\
\hline 4. & 1.25 & 99.26 \\
\hline
\end{tabular}

Table.12 Variation in EU for different operating pressure for 8 lph NPC emitter (Company A)

\begin{tabular}{|c|c|c|}
\hline Sr. No. & Operating pressure $\mathbf{( k g / \mathbf { c m } ^ { 2 } )}$ & Emission Uniformity (\%) \\
\hline 1. & 0.50 & 98.19 \\
\hline 2. & 0.75 & 99.47 \\
\hline 3. & 1.00 & 99.43 \\
\hline 4. & 1.25 & 99.17 \\
\hline
\end{tabular}


Table.13 Variation in EU for different operating pressure for 8 lph NPC emitter (Company B)

\begin{tabular}{|c|c|c|}
\hline Sr. No. & Operating pressure $\mathbf{( k g / \mathbf { c m } ^ { 2 } )}$ & Emission Uniformity (\%) \\
\hline 1. & 0.50 & 98.45 \\
\hline 2. & 0.75 & 97.23 \\
\hline 3. & 1.00 & 98.62 \\
\hline 4. & 1.25 & 99.53 \\
\hline
\end{tabular}

Table.14 Variation in EU for different operating pressure for 8 lph NPC emitter (Company C)

\begin{tabular}{|c|c|c|}
\hline Sr. No. & Operating pressure $\mathbf{( k g / \mathbf { c m } ^ { 2 } )}$ & Emission Uniformity (\%) \\
\hline 1. & 0.50 & 97.68 \\
\hline 2. & 0.75 & 97.23 \\
\hline 3. & 1.00 & 98.62 \\
\hline 4. & 1.25 & 99.67 \\
\hline
\end{tabular}

Table.15 Variation in values of UC for different pressure of 120 lph sprinkler head (Company A)

\begin{tabular}{|c|c|c|}
\hline Sr. No. & Operating pressure $\mathbf{( k g / \mathbf { c m } ^ { 2 } )}$ & Uniformity Coefficient (\%) \\
\hline 1. & 0.75 & 87.60 \\
\hline 2. & 1.00 & 89.26 \\
\hline 3. & 1.25 & 89.40 \\
\hline 4. & 1.50 & 90.13 \\
\hline
\end{tabular}

Table.16 Variation in values of UC for different pressure of 120 lph sprinkler head $\backslash$ (Company B)

\begin{tabular}{|c|c|c|}
\hline Sr. No. & Operating pressure $\mathbf{( k g / \mathbf { c m } ^ { 2 } )}$ & Uniformity Coefficient $\mathbf{( \% )}$ \\
\hline 1. & 0.75 & 86.16 \\
\hline 2. & 1.00 & 87.36 \\
\hline 3. & 1.25 & 88.65 \\
\hline 4. & 1.50 & 88.80 \\
\hline
\end{tabular}

Fig.1 Sprinkler testing set-up

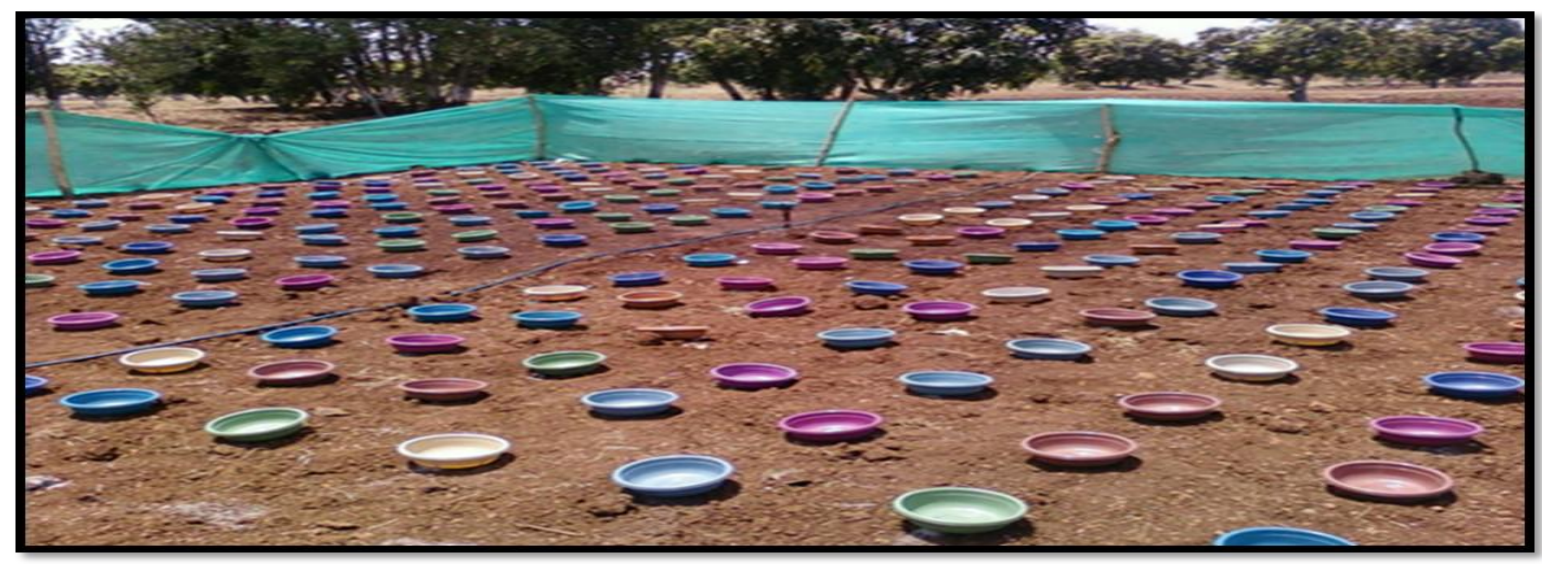


Fig.2 Pressure discharge relationship observed for 4 lph PC emitter (Company A)

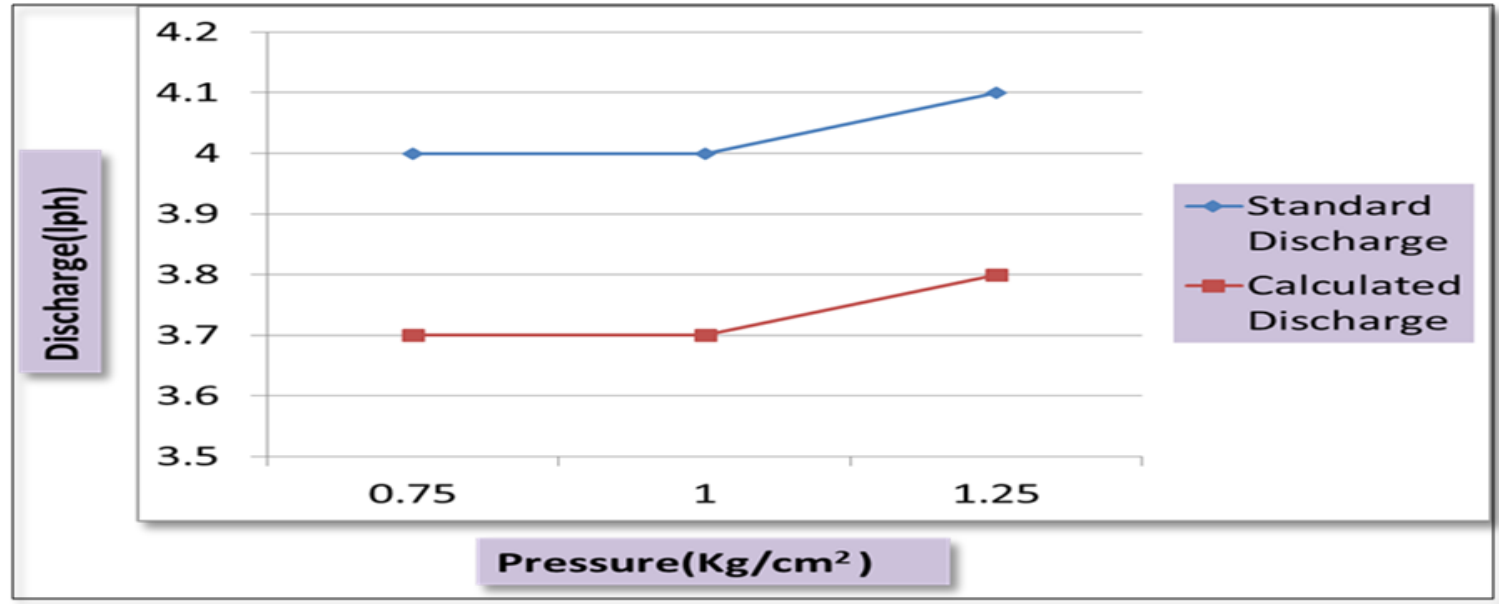

Fig.3 Pressure discharge relationship observed for 4 lph PC emitter (Company B)

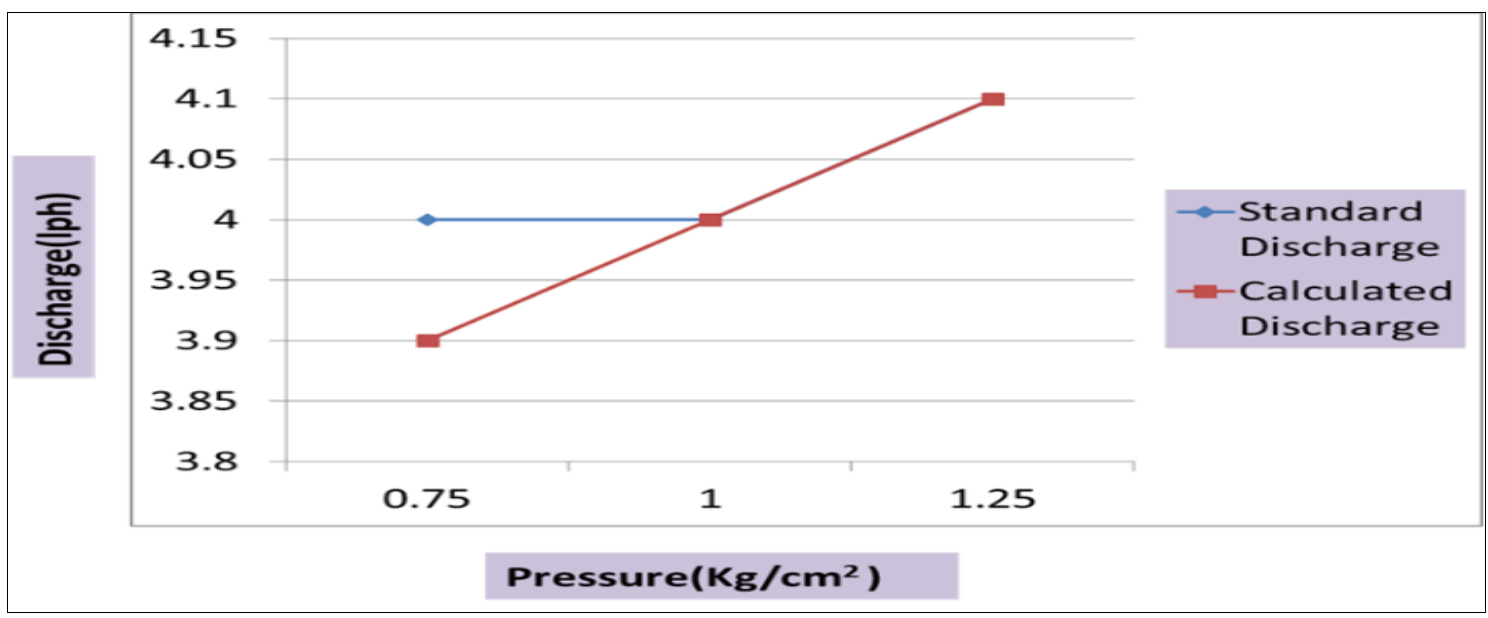

Fig.4 Pressure discharge relationship observed for 4 lph PC emitter (Company C)

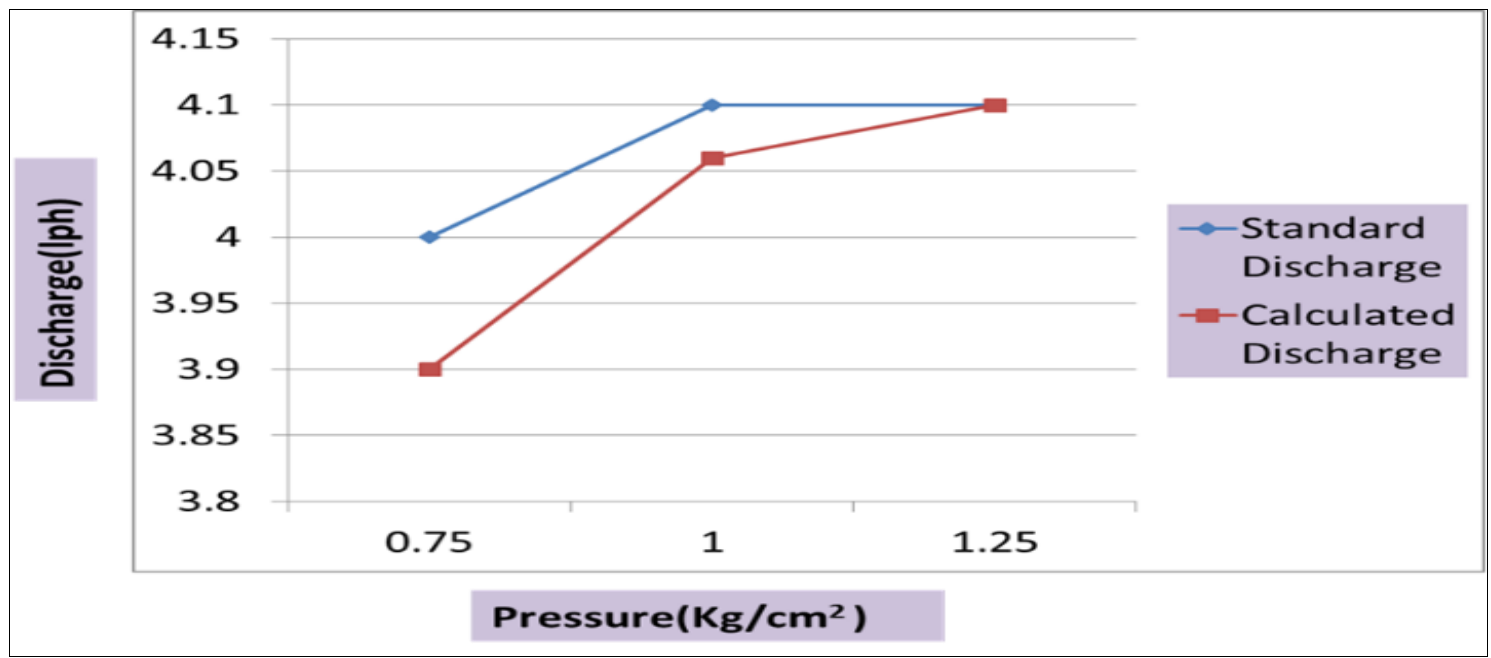


Fig.5 Variation in EU with operating pressure for 4 lph PC emitter (Company A)

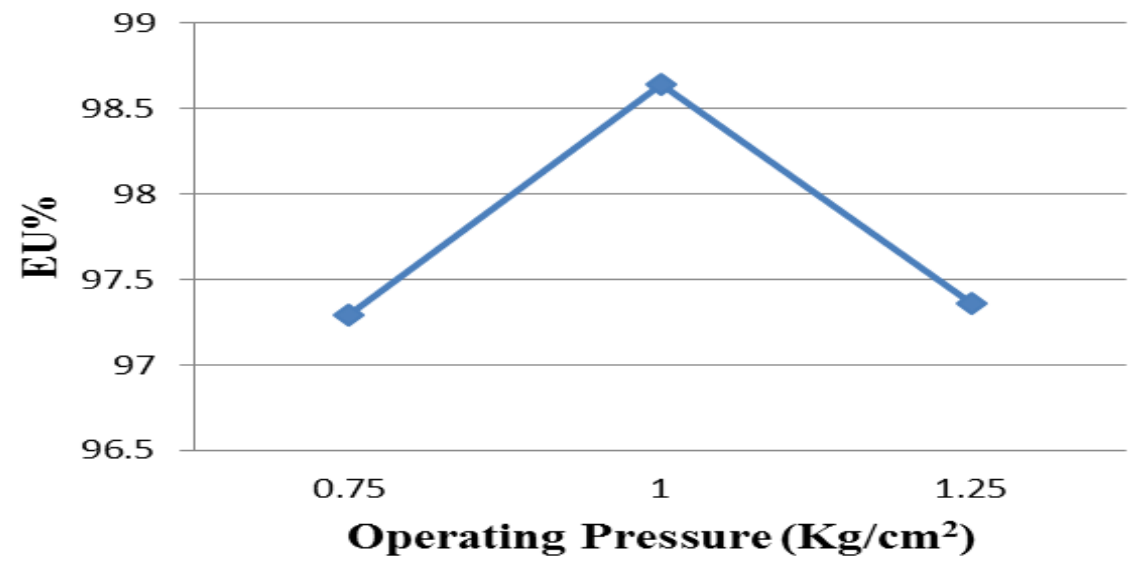

Fig.6 Variation in EU with operating pressure for 4 lph PC emitter Company B)

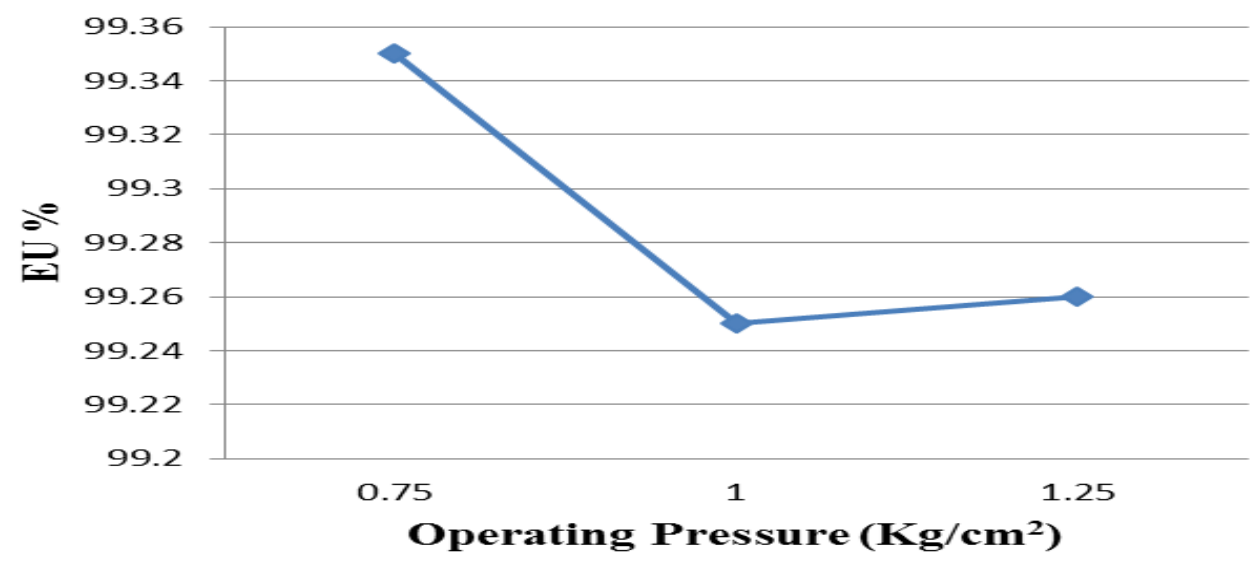

Fig.7 Variation in EU with operating pressure for 4 lph PC emitter (Company C)

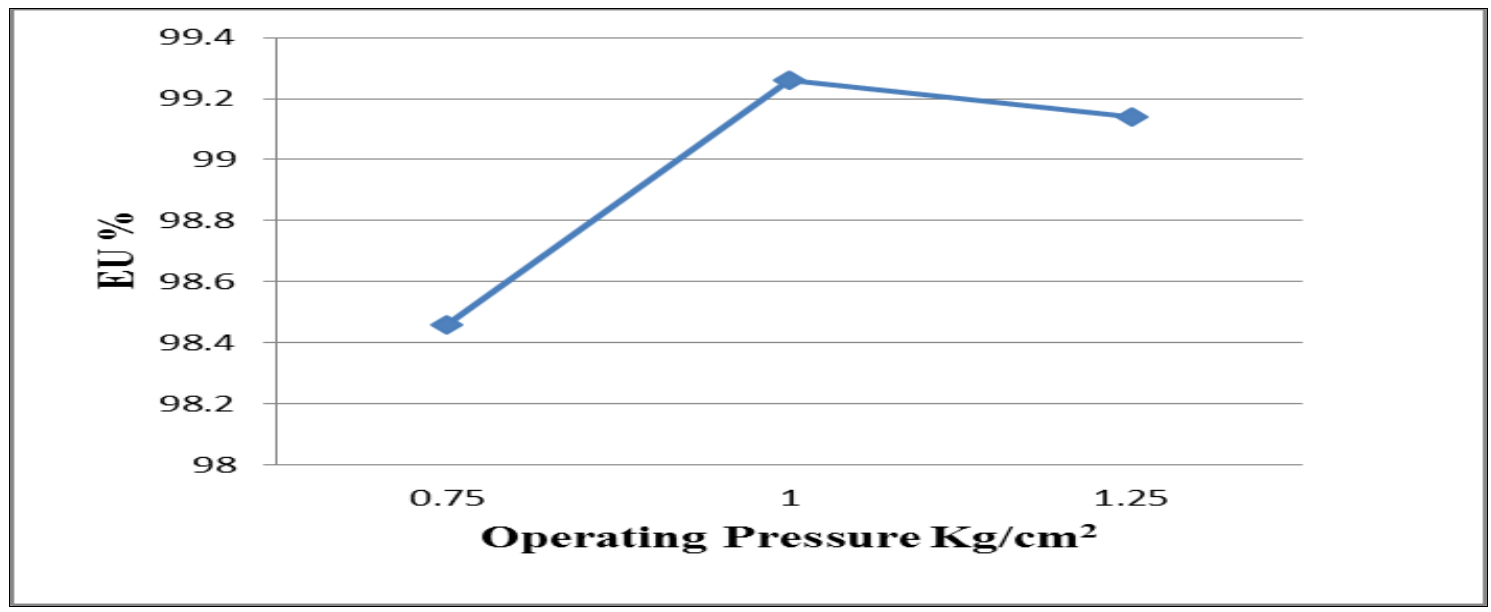




\section{Emission uniformity (EU)}

\section{NPC emitters (4 lph)}

It was observed that the minimum value of EU was $96.55 \%$ at operating pressure of 0.75 $\mathrm{kg} / \mathrm{cm}^{2}$ and maximum value of EU was $98.70 \%$ for operating pressure of $1.00 \mathrm{~kg} / \mathrm{cm}^{2}$, which means that for uniform distribution of water in the field, operating pressure should be kept at $1.00 \mathrm{~kg} / \mathrm{cm}^{2}$ (Table 9).

The maximum value of EU was $99.93 \%$ at pressure of $1.0 \mathrm{~kg} / \mathrm{cm}^{2}$. Hence for obtaining uniform distribution of water throughout field, system should be operated at $1.0 \mathrm{~kg} / \mathrm{cm}^{2}$ pressure for 4 lph NPC emitter manufactured by Company B (Table 10; Fig. 7).

The minimum value of EU was $96.66 \%$ at operating pressure of $0.50 \mathrm{~kg} / \mathrm{cm}^{2} \&$ maximum value of $\mathrm{EU}$ was $99.26 \%$ at the operating pressure of $1.25 \mathrm{~kg} / \mathrm{cm}^{2}$, which means that for obtaining uniform distribution of water in the field, the operating pressure should be kept 1.25 $\mathrm{kg} / \mathrm{cm}^{2}$ for the emitter manufactured by Company C (Table 11). Such results were also reported by Popale et al., (2011).

\section{NPC emitters (8 lph)}

It was observed that the minimum value of $\mathrm{EU}$ was $98.19 \%$ at operating pressure of 0.50 $\mathrm{kg} / \mathrm{cm}^{2} \&$ maximum value of EU was $99.47 \%$ for operating pressure of $0.75 \mathrm{~kg} / \mathrm{cm}^{2}$. There were minor variations in $\mathrm{EU}$ at operating pressure varying from 0.50 to $1.25 \mathrm{~kg} / \mathrm{cm}^{2}$. Hence for emitter of Company A uniform distribution of water will be possible if system is operated at $0.75 \mathrm{~kg} / \mathrm{cm}^{2}$ (Table 12). Similar results were reported by Changade et al., 2009.

The minimum value of EU was $97.23 \%$ at operating pressure of $0.75 \mathrm{~kg} / \mathrm{cm}^{2}$ and maximum value of EU was $99.53 \%$ at operating pressure of $1.25 \mathrm{~kg} / \mathrm{cm}^{2}$, which means that to obtain uniform distribution of water in the field, operating pressure should be kept at 1.25 $\mathrm{kg} / \mathrm{cm}^{2}$ for $8 \mathrm{lph}$ NPC emitter by Company B.
(Table 13). The minimum value of $\mathrm{EU}$ was $97.68 \%$ at operating pressure of $0.50 \mathrm{~kg} / \mathrm{cm}^{2} \&$ maximum value of EU was $99.67 \%$ at operating pressure of $1.25 \mathrm{~kg} / \mathrm{cm}^{2}$, which means that to obtain uniform distribution of water in the field, operating pressure should be kept at $1.25 \mathrm{~kg} / \mathrm{cm}^{2}$ for emitter manufactured by Company $\mathrm{C}$.

The variation in EU was very small within the operating pressure ranging from 0.75 to 1.25 $\mathrm{kg} / \mathrm{cm}^{2}$ (Table 14).

\section{PC emitters (4 lph)}

It was observed that within the operating pressure 0.75 to $1.25 \mathrm{~kg} / \mathrm{cm}^{2}$ EU varied to small extent. The minimum EU was $97.29 \%$ at operating pressure of $0.75 \mathrm{~kg} / \mathrm{cm}^{2}$ and maximum EU was $98.64 \%$ at operating pressure of $1.00 \mathrm{~kg} / \mathrm{cm}^{2}$ (Fig. 4).

It was observed that within the operating pressure 0.75 to $1.25 \mathrm{~kg} / \mathrm{cm}^{2}$, EU doesn't varied up to the large extent.

The minimum EU was $99.25 \%$ at operating pressure of $1.00 \mathrm{~kg} / \mathrm{cm}^{2}$ and the maximum EU was $98.64 \%$ at the operating pressure 0.75 $\mathrm{kg} / \mathrm{cm}^{2}$ (Fig. 5).

The minimum EU was $98.46 \%$ at operating pressure $0.75 \mathrm{~kg} / \mathrm{cm}^{2}$ and maximum EU was $99.26 \%$ for operating pressure $1.00 \mathrm{~kg} / \mathrm{cm}^{2}$. Hence for obtaining uniform distribution of water throughout field, system should be operated at $1.0 \mathrm{~kg} / \mathrm{cm}^{2}$ pressure for $4 \mathrm{lph} \mathrm{PC}$ emitter manufactured by Company C (Fig. 6). Such results were also reported by Mostafa and Thormann, 2013.

\section{Uniformity Coefficient (UC) of sprinkler}

It was observed that UC at different operating pressures ranged from $87.60 \%$ to $90.13 \%$ respectively. Highest UC of $90.13 \%$ was found at $1.5 \mathrm{~kg} / \mathrm{cm}^{2}$, which means that uniform distribution of water can be obtained at 1.5 $\mathrm{kg} / \mathrm{cm}^{2}$ operating pressure (Table 15 ). 
It was observed that highest UC was $88.80 \%$ at operating pressure $1.5 \mathrm{~kg} / \mathrm{cm}^{2}$. Hence to obtained uniform distribution of water throughout the field, the system should be operated at pressure of $1.5 \mathrm{~kg} / \mathrm{cm}^{2}$ (Table 16). Such results were also reported by Yacoubi et al., (2012).

In 4 lph and 8 lph NPC drippers manufactured byCompany $\mathrm{A}$, discharge variation with respect to pressure was less as compared to standard discharge of Company B and Company C. In 4 lph PC dripper manufactured by Company B, discharge variation with respect to pressure was very less as compared to standard discharge values of Company A and Company C.At a same pressure the UC was higher for sprinkler manufactured by Company A than sprinkler manufactured by Company B. Sprinkler of 120 lph manufactured by Company A gave excellent performance with minimum variation in discharge as compared to Company B.

\section{References}

Abdurazzaq, K. A. and Aziz, H. J. 2013. Hydraulic evaluation of drip irrigation system with different layouts. International Review of Civil Engineering, 4(3).

Changade, N. M., Chavan M. L., Jadhav S. B., and Bhagyawant R. G. 2009. Determination of emission uniformity of emitter in gravity fed drip irrigation system. International Journal of Agricultural Engineering, 2(1): 88-91.

Chavan, M. L., Khodke, U. M. and Jadhav S. B. 2009. Hydraulic performance of manually operated drip irrigation system. International Journal of Agricultural Engineering, 2(2): 273-277.

Deshmukh, Y. K., Verma V. P., Sinha J., Verma P. D. 2014. Hydraulic performance of drip irrigation system under different operating pressures. Agricultural Engineering Today, 38(3): 20-23.

Keller, J. and Karmeli, D. 1974. Trickle irrigation design parameters. Transaction of American Society of Agricultural Engineering, 17:678684.

Kyada, P. M. and Munjapara, B. J. 2013. Study on pressure discharge relationship and wetting pattern under drip irrigation system. International Journal of Science and Nature, 4(2): 273-284.

Mane, M. S. and Ayare, B. L. 2007. Principles of Sprinkler Irrigation, Jain Brothers, New Delhi.

Mane, M. S., Ayare, B. L. and Magar, S. S. 2006. Principles of Drip Irrigation, Jain Brothers, New Delhi.

Mistry, P., Memon, A., Suryanarayana, T. M. and Parekh, F. P. 2014. Evaluation of drip irrigation system for different operating pressures. International Journal of Advance Engineering and Research Development, Pp. 63-69.

Mohammed, A., Almajeed, A. and Alabas, A. 2013. Evaluation of the hydraulic performance of drip irrigation system with multi cases. Global Journal of Researches in Engineering, 13(2).

Molden, D. J., Lautze, J., Shah, T., Giordano, M. and Sanford, L. 2010. Governing to grow enough food without enough water. International Journal of Water Resource Development, 26(2): 249-263.

Mostafa, H. and Thormann, H. H. 2013. On-farm evaluation of low-pressure drip irrigation system for smallholders. Soil and Water Resources, 8: 87-95.

Popale, P. G., Bombale, V. T. and Magar, A. P. 2011. Hydraulic performance of drip irrigation system. Engineering and Technology in India, 2(1): 24-28.

Sharma, P. 2013. Hydraulic performance of drip emitters under field conditions. Journal of Agriculture and Veterinary Science, 2(1): 1520

Yacoubi, S., Zayani, K., Slatni, A. and Playan, E. 2012. Assessing sprinkler irrigation performance using field evaluations at the Medjerda lower valley of Tunisia. Engineering, 4: 682-69.

\section{How to cite this article:}

Pawar, V.L., V.D. Paradkar and Pradip Dalavi. 2017. Performance Evaluation of the Products of Different Drip and Sprinkler Irrigation Companies. Int.J.Curr.Microbiol.App.Sci. 6(12): 2321-2331. doi: https://doi.org/10.20546/ijcmas.2017.612.267 